\title{
Reptiles of the Northern Marshall Islands ${ }^{1}$
}

\author{
Donald W. Buden, ${ }^{2,7}$ Danko Taboroši, ${ }^{3}$ Maria Kottermair, ${ }^{4}$ Andrea \\ Falandoni, ${ }^{5}$ and Matthew Martin ${ }^{6}$
}

\begin{abstract}
Fifteen species of reptiles are recorded from among the nine northernmost atolls in the Republic of the Marshall Islands (RMI): 3 sea turtles, 10 lizards (3 geckos, 6 skinks, 1 monitor lizard) and 1 typhlopid snake. None is endemic to the Marshalls and all are widely distributed in Micronesia and, in many cases, well beyond. The Common House Gecko, Hemidactylus frenatus, Mariana Monitor, Varanus tsukamotoi, and Brahminy Blindsnake, Indotyphlops braminus, probably were introduced in recent times, but to what extent the other species arrived by natural dispersal, or, alternatively, by human-assisted transport at various times since the initial settlement of the islands about 2,000 years ago, is unknown. The 126 specimens of lizards collected from among eight of the atolls during March/April 2019 include the first records of terrestrial reptiles from Ailinginae Atoll, and the first records of Hemidactylus frenatus from Rongelap, Bokak, and Utirik Atolls, Gebyra oceanica from Rongelap and Taka Atolls, and Lepidodactylus lugubris from Utirik Atoll. Numerous other distribution records obtained from online databases - with the vast majority previously unreported in the literature-are included along with the earliest collection date in the RMI of $H$. frenatus and a revised early collection date for I. braminus.
\end{abstract}

Keywords: Marshall Islands, Micronesia, reptiles, distribution

AN INTERNET SEARCH FOR INFORMATION On reptiles of the Republic of the Marshall Islands (RMI) reveals an abundance of museum specimens collected from throughout the

\footnotetext{
${ }^{1}$ Manuscript accepted 21 May 2020.

${ }^{2}$ Division of Natural Sciences and Mathematics, College of Micronesia-FSM, P.O. Box 159, Kolonia, Pohnpei, 96941, Federated States of Micronesia.

${ }^{3}$ Island Research and Education Initiative (iREi), P.O. Box PS 303, Palikir, Pohnpei, 96941, Federated States of Micronesia.

${ }^{4}$ NASA Guam EPSCoR, University of Guam, University Drive, Mangilao, Guam 96923, USA.

${ }^{5}$ Place, Evolution and Rock Art Heritage Unit, Griffith Center for Social and Cultural Research, Griffith University, Queensland 4222, Australia.

${ }^{6} 26431$ S Flame Tree Drive, Sun Lakes, Arizona 85248, USA.

${ }^{7}$ Corresponding author (e-mail: don_buden@ comfsm.fm).
}

Pacific Science (2020), vol. 74, no. 2:189-209

doi: $10.2984 / 74.2 .8$

(C) 2020 by University of Hawai'i Press.

All rights reserved. archipelago, mainly since World War II, but with much of the material being unreported in the literature. This is especially so for the northern atolls where numerous biological surveys were conducted by U.S. military and civilian personnel during the 1940s through the 1960 s, broadly overlapping the period of U.S. nuclear-weapons testing within the region, 1946-1958. Aside from Lamberson's (1987a) review of the reptiles of Enewetak Atoll, herpetological accounts of the northern atolls of the RMI are largely limited to passing comments in expedition reports that focused more on the vegetation and/or avifauna (e.g., Fosberg 1955, 1990, Amerson 1969, Thomas et al. 1989) or to articles specifically on sea turtles (e.g., Fosberg 1969, Hendrickson 1972, Pritchard 1977, Puleloa and Kilma 1992; McCoy 2004, 2008). In March and April 2019, we visited eight of the nine northernmost atolls in the Marshalls (to the exclusion only of Enewetak) to gather biological, cultural, and geographical information to be included in the forthcoming first national atlas of the Republic 
of the Marshall Islands. The present paper is on the reptiles observed and collected during these visits. It includes information gleaned from the literature as well as numerous previously unpublished locality records from online databases.

\section{Study Area}

The island nation of the Republic of the Marshall Islands is made up of 29 atolls and five stand-alone mid-ocean reef islands in the west-central Pacific Ocean, between $4^{\circ}$ and $15^{\circ} \mathrm{N}$ and $160^{\circ}$ and $173^{\circ} \mathrm{E}$. None of the atoll or stand-alone islands is larger than $5.0 \mathrm{~km}^{2}$ and most are less than $1.0 \mathrm{~km}^{2}$ (Bryan 1971). The maximum elevation for the RMI is recorded as $10.0 \mathrm{~m}$ on Likiep Atoll (http:// www.peakbagger.com/peak.aspx? pid=11788), but most of the Marshall Islands are no more than about 2-4 $\mathrm{m}$ above sea level. The islands are arranged in a double chain approximately $1,300 \mathrm{~km}$ long (northwest to southeast) and $1,150 \mathrm{~km}$ wide: the Ralik chain to the west and the Ratak chain to the east (Figure 1). Warm tropical conditions persist year-round, but a marked precipitation gradient extends from north to south with annual rainfall ranging from as little as $635 \mathrm{~mm}$ in the north to more than $4,000 \mathrm{~mm}$ in the south (National Biodiversity Team of the Republic of the Marshall Islands 2000). The vegetation correspondingly grades from xerophytic scrub and forest in the north to increasingly more mesic woodlands in the south (Fosberg 1990, Mueller-Dombois and Fosberg 1998).

The northern Marshalls in this study include the nine atolls north of $11^{\circ}$ north latitude-Enewetak, Bikini, Ailinginae, Rongelap, Rongerik, Bokak, Bikar, Utirik, and Taka (Figure 1). All are near, or in some cases well beyond, the northern limits of permanent human habitation in the Marshall Islands as determined largely by the amount of rainfall needed to support vital tree crops and maintain a sufficient ground-water supply (Weisler 2001a,b). Only Enewetak and Utirik now have occupied settlements. Bikini and Rongelap Atolls, which were once permanently occupied, now have transient caretakers more or less on a rotating basis to maintain facilities; residents were relocated and prevented from returning because of radioactive contamination of the islands from nuclear tests. The five other atolls are uninhabited and have no history of long-term human occupation, but are visited from time to time by Marshallese from other atolls to harvest fish, crabs, turtles, birds, and other island resources. Enewetak and Bikini Atolls were impacted directly by nuclear test detonations during the 1940s and 50s, with some of the islands being completely destroyed (vaporized). The Castle-Bravo test at Bikini Atoll in 1954 resulted in the most powerful explosion in U.S. nuclear testing history, with radioactive fallout extending downwind to Ailinginae, Rongelap, Rongerik, Bikar, Utirik, and Taka Atolls. The biota has demonstrated considerable resiliency in the wake of nuclear testing. Fosberg (1988:1) remarked that nuclear tests at Bikini during 1946 to 1958 resulted in "the destruction or serious alteration of all vegetation," but by the time of his visit in 1985, "native forest and scrub vegetation had recovered to a surprising extent." A Stanford University research team found marine life thriving and apparently healthy in the waters surrounding Bikini during their visit in 2016 (Lippert 2017, Scott 2017); genetic studies of samples they collected are ongoing (E. López, pers. comm.). However, a recent study on radiological conditions in the northern Marshalls by researchers from Columbia University reported much higher levels of contamination in parts of Enewetak, Bikini, and Rongelap Atolls than are considered safe for humans (Rust 2019). The Columbia team (Abella et al. 2019) cautioned that people living in southern Enewetak Atoll should be warned against spending time on the northern islands, that radiation levels on Bikini Island, where most of the residents of Bikini Atoll lived before being relocated, are too high for resettlement, and that clean-up of extremely high levels of radioactive contamination on Naen and possibly other northern Rongelap Atoll islands are needed before full atoll resettlement can be envisioned.

Coastal scrub and xerophytic hardwood forest (Pisonia grandis, Guettarda speciosa, and Cordia subcordata being dominant), and coconut (Cocos nucifera) forest-with a scatter- 


\section{MARSHALL ISLANDS}

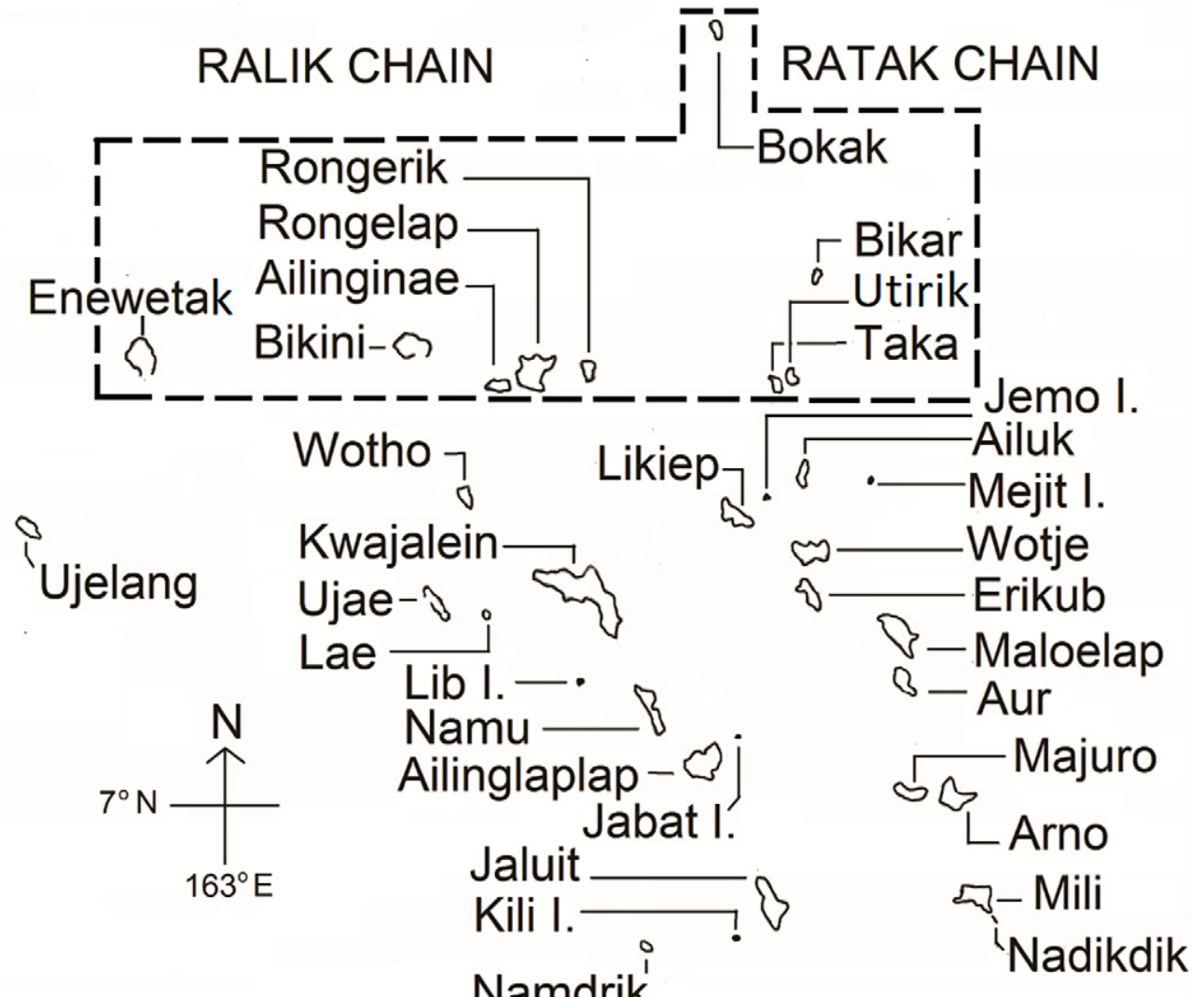

Namdrik

Ebon- 0

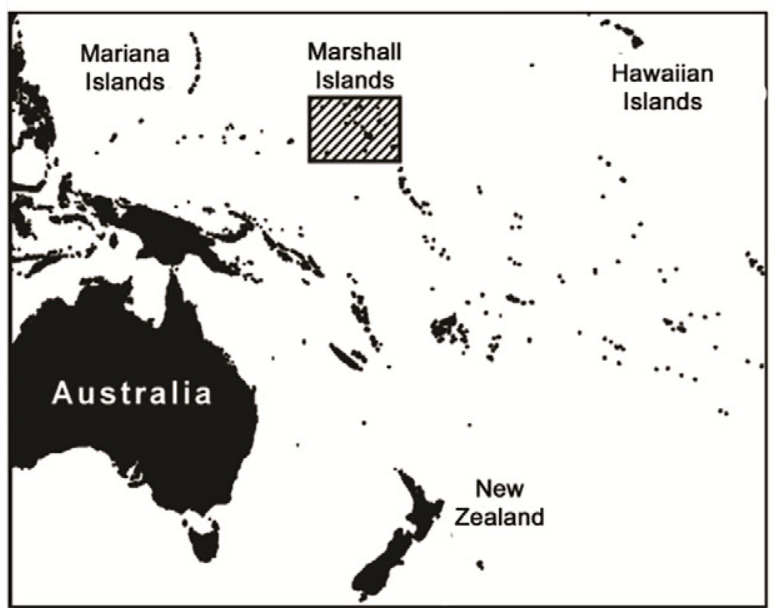

$200 \mathrm{~km}$

FIGURE 1. Location map for the Marshall Islands; study area delineated by dashed line. 
ing of Pandanus tectorius - are the main vegetation types throughout most of the northern Marshalls. Bokak, the northernmost atoll in the RMI, has a semidesert aspect with low scrub forest dominated by Scaevola taccada and Tournefortia argentea. Reports of coconut trees being recently introduced to Bokak, and Australian Pine, Casuarina equisetifolia, to both Bokak and Bikar (see McCoy 2004) remain unconfirmed by us following our visits to Bikar Island and to four of the largest islands on Bokak Atoll. Detailed descriptions of vegetation on the northern atolls are provided by Taylor (1950), Fosberg (1955, 1988, 1990), Lamberson (1987b), Thomas et al. (1989), Bridges and McClatchey (2005), Stevens Releford (2009), and Stevens Releford et al. (2009).

\section{MATERIALS AND METHODS}

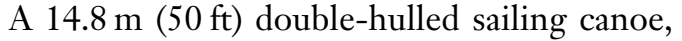
the Okeanos Marshall Islands, chartered out of Majuro, capital of the Marshall Islands, provided access to the northern atolls of the RMI during March and April 2019: Utirik Atoll (29-31 March), Taka Atoll (31 March-1 April), Bikar Atoll (2-3 April), Bokak Atoll (4-6 April), Rongerik Atoll (8-9 April), Rongelap Atoll (10-11 April), Ailinginae Atoll (12-14 April), and Bikini Atoll (15-17 April). An inflatable dinghy and kayaks were used to reach island shores from the vessel when it was anchored in the lagoon or just outside the reef when access into the lagoon was not feasible.

Turtle tracks counted during the present study are recorded as pairs, with each pair consisting of an emergent and returning set. The number of tracks recorded by Fosberg (1969) and Hendrickson (1972) are of emerging and returning sets combined. The methods used for counts made by Thomas et al. (1989), with the terms pairs and sets being used interchangeably, and Puleloa and Kilma (1992) were not specified in their reports. Our observations on sea turtles are supplemented by information provided by local residents interviewed by D.T.

Lizards were collected by hand and specimens were fixed in 10\% formalin, washed, and stored in 35\% isopropanol, with the exception of two Cryptoblepharus poecilopleurus and seven Lepidodactylus lugubris preserved in ethanol for possible later genetic studies (Table 2). Specimens are in the Division of Natural Sciences and Mathematics, College of MicronesiaFSM.

Additional locality records of snakes and lizards were obtained from the VertNet data portal and online databases of individual natural history museums. Museum abbreviations are: AMNH (American Museum of Natural History, New York), BPBM (Bernice P. Bishop Museum, Honolulu, Hawaii), CAS (California Academy of Sciences, San Francisco, California [CAS-SU and CAS-SUR include merged Stanford University reptile collections]), HSU (Humboldt State University Vertebrate Museum, Arcata, California), KU (University of Kansas Biodiversity Institute, Lawrence, Kansas), LACM (Natural History Museum of Los Angeles County, California), MCZ (Museum of Comparative Zoology, Harvard University, Cambridge, Massachusetts), MVZ (Museum of Vertebrate Zoology, University of California, Berkeley, California), UAZ (University of Arizona Museum of Natural History, Tucson, Arizona), UF (University of Florida, Florida Museum of Natural History, Gainesville, Florida), UMMZ (University of Michigan Museum of Zoology, Ann Arbor, Michigan), UNR (University of Nevada, Reno, Museum of Natural History, Reno, Nevada), USNM (National Museum of Natural History, Smithsonian Institution, Washington, D.C. [includes specimens formerly in Mid-Pacific Research Laboratory (MPRL), Enewetak Atoll]), and UWBM (University of Washington, Burke Museum of Natural History and Culture, Seattle, Washington).

Many localities within the Marshall Islands have potentially confusing alternative names along with variations in spelling. The names Enewetak, Eniwetok, and Eniwetak, for example, can apply to an atoll (Enewetak in this study), one of the islands on that atoll, an island on Rongerik Atoll, or another island on Kwajalein Atoll. Also, Fosberg (1990) used the name Eniwetak for an island on Rongelap Atoll, possibly referring to Eniaetok Island. Island names used in the present study are 
TABLE 1

Names, Geographic Coordinates, and Alternative Names of Islands in the Northern Marshall Islands Included in this Study

\begin{tabular}{|c|c|c|}
\hline Island Names & Coordinates & Alternative Island Names \\
\hline \multicolumn{3}{|l|}{ Ralik Chain } \\
\hline Enewtak Atoll & & Eniwetok Atoll, Eniwetak Atoll \\
\hline Alembel & $11^{\circ} 36^{\prime} 08^{\prime \prime} \mathrm{N}, 162^{\circ} 19^{\prime} 52^{\prime \prime} \mathrm{E}$ & Arambiru, Vera \\
\hline Aniyaanii & $11^{\circ} 28^{\prime} 04^{\prime \prime} \mathrm{N}, 162^{\circ} 23^{\prime} 37^{\prime \prime} \mathrm{E}$ & Ananij, Japtan/Bruce \\
\hline Billee & $11^{\circ} 38^{\prime} 47^{\prime \prime} \mathrm{N}, 162^{\circ} 15^{\prime} 10^{\prime \prime} \mathrm{E}$ & Lucy, Kidrinen \\
\hline Boken/Irene & $11^{\circ} 40^{\prime} 22^{\prime \prime} \mathrm{N}, 162^{\circ} 12^{\prime} 45^{\prime \prime} \mathrm{E}$ & Irene \\
\hline Boken/Irwin & $11^{\circ} 21^{\prime} 19^{\prime \prime} \mathrm{N}, 162^{\circ} 11^{\prime} 18^{\prime \prime} \mathrm{E}$ & Irwin \\
\hline Elugelab $^{\mathrm{a}}$ & $11^{\circ} 40^{\prime} 12^{\prime \prime} \mathrm{N}, 162^{\circ} 11^{\prime} 41^{\prime \prime} \mathrm{E}$ & Flora \\
\hline Enewetak & $11^{\circ} 20^{\prime} 40^{\prime \prime} \mathrm{N}, 162^{\circ} 20^{\prime} 00^{\prime \prime} \mathrm{E}$ & Eniwetok, Eniwetak, Fred \\
\hline Enjebi & $11^{\circ} 39^{\prime} 49^{\prime \prime} \mathrm{N}, 162^{\circ} 14^{\prime} 25^{\prime \prime} \mathrm{E}$ & Janet \\
\hline Igurin & $11^{\circ} 20^{\prime} 38^{\prime \prime} \mathrm{N}, 162^{\circ} 13^{\prime} 29^{\prime \prime} \mathrm{E}$ & Ikuren, Glenn \\
\hline Japtan/David & $11^{\circ} 25^{\prime} 28^{\prime \prime} \mathrm{N}, 162^{\circ} 22^{\prime} 59^{\prime \prime} \mathrm{E}$ & Muti \\
\hline Lujor & $11^{\circ} 37^{\prime} 37^{\prime \prime} \mathrm{N}, 162^{\circ} 17^{\prime} 48^{\prime \prime} \mathrm{E}$ & Ruby \\
\hline Mui & $11^{\circ} 21^{\prime} 00^{\prime \prime} \mathrm{N}, 162^{\circ} 12^{\prime} 05^{\prime \prime} \mathrm{E}$ & Mut, Buganegan, Henry \\
\hline Perry & $11^{\circ} 24^{\prime} 03^{\prime \prime} \mathrm{N}, 162^{\circ} 22^{\prime} 13^{\prime \prime} \mathrm{E}$ & Parry, Elmer, Medren \\
\hline Piirai & $11^{\circ} 35^{\prime} 24^{\prime \prime} \mathrm{N}, 162^{\circ} 19^{\prime} 46^{\prime \prime} \mathrm{E}$ & Billae, Wilma \\
\hline Ribewon & $11^{\circ} 21^{\prime} 50^{\prime \prime} \mathrm{N}, 162^{\circ} 10^{\prime} 24^{\prime \prime} \mathrm{E}$ & James \\
\hline Rigili & $11^{\circ} 27^{\prime} 25^{\prime \prime} \mathrm{N}, 162^{\circ} 05^{\prime} 22^{\prime \prime} \mathrm{E}$ & Biken, Leroy \\
\hline Runit & $11^{\circ} 32^{\prime} 37^{\prime \prime} \mathrm{N}, 162^{\circ} 21^{\prime} 15^{\prime \prime} \mathrm{E}$ & Uni, Ruuit, Yvonne \\
\hline Van & $11^{\circ} 29^{\prime} 31^{\prime \prime} \mathrm{N}, 162^{\circ} 23^{\prime} 04^{\prime \prime} \mathrm{E}$ & \\
\hline \multicolumn{3}{|l|}{ Bikini Atoll } \\
\hline Airukiiji & $11^{\circ} 30^{\prime} 33^{\prime \prime} \mathrm{N}, 165^{\circ} 24^{\prime} 32^{\prime \prime} \mathrm{E}$ & \\
\hline Aomoen & $11^{\circ} 41^{\prime} 30^{\prime \prime} \mathrm{N}, 165^{\circ} 25^{\prime} 40^{\prime \prime} \mathrm{E}$ & \\
\hline Bikini & $11^{\circ} 37^{\prime} 40^{\prime \prime} \mathrm{N}, 165^{\circ} 32^{\prime} 54^{\prime \prime} \mathrm{E}$ & \\
\hline Bokororyuru & $11^{\circ} 34^{\prime} 36^{\prime \prime} \mathrm{N}, 165^{\circ} 03^{\prime} 12^{\prime \prime} \mathrm{E}$ & \\
\hline Chieerete & $11^{\circ} 31^{\prime} 36^{\prime \prime} \mathrm{N}, 165^{\circ} 17^{\prime} 06^{\prime \prime} \mathrm{E}$ & \\
\hline Eninman & $11^{\circ} 30^{\prime} 12^{\prime \prime} \mathrm{N}, 165^{\circ} 22^{\prime} 49^{\prime \prime} \mathrm{E}$ & Eman \\
\hline Enyu & $11^{\circ} 31^{\prime} 31^{\prime \prime} \mathrm{N}, 165^{\circ} 33^{\prime} 59^{\prime \prime} \mathrm{E}$ & \\
\hline Namu & $11^{\circ} 42^{\prime} 07^{\prime \prime} \mathrm{N}, 165^{\circ} 17^{\prime} 29^{\prime \prime} \mathrm{E}$ & Nam \\
\hline Ourukaen & $11^{\circ} 33^{\prime} 45^{\prime \prime} \mathrm{N}, 165^{\circ} 14^{\prime} 07^{\prime \prime} \mathrm{E}$ & \\
\hline Romurikku & $11^{\circ} 41^{\prime} 52^{\prime \prime} \mathrm{N}, 165^{\circ} 24^{\prime} 49^{\prime \prime} \mathrm{E}$ & Romuk \\
\hline Uorikku $^{\text {b }}$ & $11^{\circ} 41^{\prime} 49^{\prime \prime} \mathrm{N}, 165^{\circ} 24^{\prime} 12^{\prime \prime} \mathrm{E}$ & \\
\hline Yurochi & $11^{\circ} 41^{\prime} 37^{\prime \prime} \mathrm{N}, 165^{\circ} 23^{\prime} 24^{\prime \prime} \mathrm{E}$ & \\
\hline \multicolumn{3}{|l|}{ Ailinginae Atoll } \\
\hline Enibuk & $11^{\circ} 07^{\prime} 31^{\prime \prime} \mathrm{N}, 166^{\circ} 21^{\prime} 40^{\prime \prime} \mathrm{E}$ & \\
\hline Knox & $11^{\circ} 07^{\prime} 00^{\prime \prime} \mathrm{N}, 166^{\circ} 31^{\prime} 42^{\prime \prime} \mathrm{E}$ & \\
\hline Manchinikon & $11^{\circ} 08^{\prime} 19^{\prime \prime} \mathrm{N}, 166^{\circ} 18^{\prime} 24^{\prime \prime} \mathrm{E}$ & \\
\hline Mogiri & $11^{\circ} 07^{\prime} 29^{\prime \prime} \mathrm{N}, 166^{\circ} 20^{\prime} 29^{\prime \prime} \mathrm{E}$ & Mokil \\
\hline Sifo & $11^{\circ} 08^{\prime} 44^{\prime \prime} \mathrm{N}, 166^{\circ} 17^{\prime} 26^{\prime \prime} \mathrm{E}$ & \\
\hline \multicolumn{3}{|l|}{ Rongelap Atoll } \\
\hline Arbar & $11^{\circ} 09^{\prime} 53^{\prime \prime} \mathrm{N}, 166^{\circ} 46^{\prime} 07^{\prime \prime} \mathrm{E}$ & \\
\hline Bikenerer & $11^{\circ} 27^{\prime} 55^{\prime \prime} \mathrm{N}, 166^{\circ} 41^{\prime} 20^{\prime \prime} \mathrm{E}$ & Bokenkear, Yugui \\
\hline Burok & $11^{\circ} 14^{\prime} 26^{\prime \prime} \mathrm{N}, 166^{\circ} 37^{\prime} 28^{\prime \prime} \mathrm{E}$ & \\
\hline Erapuotsu & $11^{\circ} 18^{\prime} 28^{\prime \prime} \mathrm{N}, 166^{\circ} 53^{\prime} 53^{\prime \prime} \mathrm{E}$ & \\
\hline Kabelle & $11^{\circ} 26^{\prime} 50^{\prime \prime} \mathrm{N}, 167^{\circ} 03^{\prime} 31^{\prime \prime} \mathrm{E}$ & \\
\hline Lukuen & $11^{\circ} 26^{\prime} 57^{\prime \prime} \mathrm{N}, 166^{\circ} 54^{\prime} 37^{\prime \prime} \mathrm{E}$ & \\
\hline Naen & $11^{\circ} 27^{\prime} 57^{\prime \prime} \mathrm{N}, 166^{\circ} 41^{\prime} 00^{\prime \prime} \mathrm{E}$ & \\
\hline Rongelap & $11^{\circ} 09^{\prime} 33^{\prime \prime} \mathrm{N}, 166^{\circ} 53^{\prime} 29^{\prime \prime} \mathrm{E}$ & \\
\hline Yuguic $^{\mathrm{c}}$ & $11^{\circ} 27^{\prime} 47^{\prime \prime} \mathrm{N}, 166^{\circ} 47^{\prime} 44^{\prime \prime} \mathrm{E}$ & \\
\hline
\end{tabular}


TABLE 1

\begin{tabular}{|c|c|c|}
\hline Island Names & Coordinates & Alternative Island Names \\
\hline \multicolumn{3}{|l|}{ Rongerik Atoll } \\
\hline Bigonattam & $11^{\circ} 23^{\prime} 24^{\prime \prime} \mathrm{N}, 167^{\circ} 30^{\prime} 32^{\prime \prime} \mathrm{E}$ & Bigonattum \\
\hline Bock & $11^{\circ} 23^{\prime} 14^{\prime \prime} \mathrm{N}, 167^{\circ} 21^{\prime} 51^{\prime \prime} \mathrm{E}$ & Bok \\
\hline Eniwetak & $11^{\circ} 17^{\prime} 52^{\prime \prime} \mathrm{N}, 167^{\circ} 28^{\prime} 19^{\prime \prime} \mathrm{E}$ & \\
\hline Latoback & $11^{\circ} 24^{\prime} 18^{\prime \prime} \mathrm{N}, 167^{\circ} 28^{\prime} 55^{\prime \prime} \mathrm{E}$ & \\
\hline Rongerik & $11^{\circ} 22^{\prime} 42^{\prime \prime} \mathrm{N}, 167^{\circ} 30^{\prime} 54^{\prime \prime} \mathrm{E}$ & \\
\hline Tarrowatt & $11^{\circ} 20^{\prime} 12^{\prime \prime} \mathrm{E}, 167^{\circ} 29^{\prime} 49^{\prime \prime} \mathrm{E}$ & \\
\hline \multicolumn{2}{|l|}{ Bokak Atoll } & Taongi Atoll, Pokak Atoll \\
\hline Bokak & $14^{\circ} 34^{\prime} 50^{\prime \prime} \mathrm{N}, 168^{\circ} 57^{\prime} 23^{\prime \prime} \mathrm{E}$ & \\
\hline Sibylla & $14^{\circ} 36^{\prime} 23^{\prime \prime} \mathrm{N}, 168^{\circ} 59^{\prime} 50^{\prime \prime} \mathrm{E}$ & \\
\hline \multicolumn{3}{|l|}{ Bikar Atoll } \\
\hline Almani & $12^{\circ} 14^{\prime} 36^{\prime \prime} \mathrm{N}, 170^{\circ} 08^{\prime} 02^{\prime \prime} \mathrm{E}$ & \\
\hline Bikar & $12^{\circ} 11^{\prime} 22^{\prime \prime} \mathrm{N}, 170^{\circ} 06^{\prime} 26^{\prime \prime} \mathrm{E}$ & \\
\hline Jabwelo & $12^{\circ} 14^{\prime} 59^{\prime \prime} \mathrm{N}, 170^{\circ} 08^{\prime} 23^{\prime \prime} \mathrm{E}$ & Jahoerrhu \\
\hline \multicolumn{3}{|l|}{ Utirik Atoll } \\
\hline Utirik & $11^{\circ} 13^{\prime} 34^{\prime \prime} \mathrm{N}, 169^{\circ} 51^{\prime} 03^{\prime \prime} \mathrm{E}$ & \\
\hline \multicolumn{3}{|l|}{ Taka Atoll } \\
\hline Eluk & $11^{\circ} 04^{\prime} 50^{\prime \prime} \mathrm{N}, 169^{\circ} 37^{\prime} 51^{\prime \prime} \mathrm{E}$ & \multirow{4}{*}{ Lojrong } \\
\hline Lojiron & $11^{\circ} 07^{\prime} 22^{\prime \prime} \mathrm{N}, 169^{\circ} 39^{\prime} 49^{\prime \prime} \mathrm{E}$ & \\
\hline Taka & $11^{\circ} 06^{\prime} 49^{\prime \prime} \mathrm{N}, 169^{\circ} 39^{\prime} 55^{\prime \prime} \mathrm{E}$ & \\
\hline Watwerok & $11^{\circ} 09^{\prime} 00^{\prime \prime} \mathrm{N}, 169^{\circ} 39^{\prime} 35^{\prime \prime} \mathrm{E}$ & \\
\hline
\end{tabular}

those that appear most frequently in the literature and natural history museum herpetological databases; alternative names used less frequently are included in brackets. Geographic coordinates (Table 1) are from Google Earth satellite images. Sources of place names with accompanying location maps include Bender (1963), Amerson (1969), Bryan (1971), and Helfrich and May (1987). Ralik Chain atolls are listed west to east and Ratak Chain atolls north to south; islands are listed in alphabetical order for each atoll along with the total number of specimens recorded for each island from all museum database records combined.

\section{RESULTS}

\section{Sea Turtles}

Chelonia mydas (Linnaeus) - The northern atolls of the Ratak Chain are the main nesting sites for Green Turtles in the RMI, and nesting has been reported on all nine atolls included in this study (Pritchard 1977, McCoy 2004, Maison et al. 2010). However, the current status of many nesting sites active in the past is unknown, and reports of nesting on Bokak Atoll need confirmation (see Discussion).

Enewetak Atoll: Helfich (in Pritchard 1977) reported that turtles nested on many islands throughout the atoll at least until the mid-1940s, Lamberson (1987a) remarked on a possible [1980s?] incidence of nesting on Ikuren Island, and an anonymous source (in McCoy 2004:70) reported that "turtles no longer come ashore to lay eggs."

Bikini Atoll: Maison et al. (2010) included Bikini Atoll as one of several minor nesting sites of Green Turtles in the RMI, citing McCoy (2004) as a source. Tracks were observed on northwest beaches of Bikini Island, October 2003 (Vander Velde in McCoy 2004, and pers. comm.) and hundreds of hatchlings were seen scrambling across the 
beach to the lagoon on Nam (= Namu) Island during the afternoon of 9 August 2018 (Rust 2019 and pers. comm.). Numerous tracks and a dead turtle were observed on Nam (M.K. and A.J.), and one set of tracks was followed for about $75 \mathrm{~m}$ along an $850 \mathrm{~m}$-long, 30-40 $\mathrm{m}$-wide sandy isthmus between Uorikku and Yurochi Islands, ending where the turtle returned to water after finding no place to nest, 17 April 2019 (M.M.). Herington Jejak (interviewed by D.T.) remarked that turtles nest widely throughout the atoll, with Nam and Bikini Islands being the main nesting sites, and that once or twice a year, especially during the Christmas and New Year holiday season, local workers go to the ocean side of Bikini to hunt for a turtle to eat.

Ailinginae Atoll: Turtles were tagged and measured on unspecified nesting beaches in 2002 (V. Pepi in McCoy 2004), and nesting was recorded on Manchinikon and Sifo Islands, undated but probably 2002 or 2003 (L. Tobin in McCoy 2004). About 100 eggs were collected by the Okeanos crew from a nest on Mogiri Island (photographed by M.K.) and 18 pairs of tracks were counted on Sifo Island (M.K. and A.J.), 13 April 2019.

Rongelap Atoll: Leigh Tobin (in McCoy 2004) reported Green Turtles nesting on Rongelap Island and on islands along northeastern side of the atoll, undated but probably 2003; Joe Jobtak (interviewed by D.T.) stated that turtles nest on all the islands, but mainly on Burok and the islands on the western side of the atoll. Five pairs of tracks were seen on Bikenerer Island (M.K. and A.J.) and several others on Lukuen Island (D.T.), 11 April 2019, and one turtle was seen swimming near the lagoon-side shore of Arbar Island (M.K. and M.M.), 12 April 2019.

Rongerik Atoll: Thirty three pairs of tracks were counted on Eniwetak Island and one pair on Tarrowatt Island, 20-21 September 1988 (Thomas et al. 1989), and many nests were observed (30 counted during one night on one island), undated but probably 2003 (L. Tobin in McCoy 2004). Sixty-one pairs of tracks were counted on Bock Island (M.K. and A.J.), two turtles were seen in the lagoon (D.T.), 106 pairs of tracks were counted on Eniwetak
Island, 16 of them appearing to be only one or two days old (M.K. and A.J.), and six turtles were seen together in the lagoon, possibly getting ready to come ashore at night (D.T.), all 9 April 2019.

Bokak Atoll: No confirmed records-see Discussion.

Bikar Atoll: "Likely supports the largest green turtle nesting assemblage in the RMI" (Maison et al. 2010:12); 237 turtles estimated nesting annually based on observations during 2-3 July 1971 (Hendrickson 1972); 596 tracks counted on 6 August, eggs observed being laid in newly constructed nests, and hatchlings seen emerging from older nests, all on Bikar Island, 6-12 August 1952 (Fosberg 1969); no turtles seen on land, but one pair observed mating on ocean side of channel and "over 264 sets of nesting tracks were observed [Bikar 176, Jabwelo 74, Almani 14] . . . together with numerous new and old nest sites," 12-13 September 1988 (Thomas et al. 1989:42); 48 turtles tagged, hatchlings seen emerging from two nest sites, and tracks too numerous and intermingled to count accurately, all on Bikar Island, and numerous turtle excavations observed on Jabwelo (at least 100) and Almani (at least 50) during 1-11 August 1992 (Puleloa and Kilma 1992). Many intermingled tracks were observed during 2-3 April 2019, with at least six pairs being made during the night (M.K. and A.J.).

Utirik Atoll: Weisler (2001a,b) reported on turtle bones collected from archaeological surveys during the mid-1990s and remarked that C. mydas still nested on several islands, including Utirik Island, not far from the village. He (Weisler 2001b:103) stated that "nesting sites were observed on the upper ocean side beach of Utrōk islet during December to January... [and] turtle eggs and meat were available in the village on several occasions during this time."

Taka Atoll: Twenty four sets of tracks were observed during 14-15 September 1988-Taka 16, Lojrong 4, Eluk 4 (Thomas et al. 1989). The ocean side of Eluk Island was pockmarked with turtle nests of various ages, and one long-dead turtle was seen trapped under a Tournefortia tree, 1 April 2019 (D.T.). 
Eretmochelys imbricata (Linnaeus) Hawksbill Turtles occur throughout the Marshall Islands but are much less frequently encountered than Green Turtles, and records of nesting are scarce (McCoy 2004, 2008). Hawksbills have been reported from all but Bokak and Utirik among the nine atolls included in this study, but many of the sightings are based on tentative identifications and lack adequate documentation:

Enewetak Atoll: Lamberson (1987a) and an unnamed part-time resident (in McCoy 2004) reported Hawksbills as present but without further elaboration.

Bikini Atoll: Nancy VanderVelde (in McCoy 2004, and pers. comm.) reported one "possible" sighting in the lagoon and one "probable" sighting on the reef, October 2003 and Jiki Wottokna (interviewed by D.T.) remarked that Hawksbills nest on Bikini Island.

Ailinginae Atoll: James Maragos (in McCoy 2004) observed a subadult in the lagoon, mid-2002, and Leigh Tobin (in McCoy 2004) reported that Hawksbills accounted for $30-40 \%$ of all turtle sightings, date unspecified but probably 2002; reports of nesting on the atoll (Ronald Alfred in Eckert 1992) require confirmation.

Rongelap Atoll: L. Tobin (in McCoy 2004) reported Hawksbills present (date unspecified but probably 2002 or 2003), and Fred Anjain (interviewed by D.T.) reported that approximately two months prior to our arrival in April 2019, a Hawksbill came ashore at Jaboan Village, Rongelap Island, where the people allowed it to lay eggs and return to the water unharmed. It was the first Hawksbill seen by Anjain in the past 20 years.

Rongerik Atoll: Hawksbills were reported to account for about $30-40 \%$ of the turtle sightings, and nesting tracks [of one turtle?] were identified by their small size and the markings left by the plastron, undated but probably 2003 (L. Tobin in McCoy 2004). At least two, possibly three, Hawksbills (one missing its back left leg) were seen in the water on the lagoon side of Rongerik Island, 8 April 2019 (D.T. and M. M.).

Bikar Atoll: One set of Hawksbill tracks was recorded on Bikar Island during 2-3 July
1971 (Hendrickson 1972), and another set identified as probably those of a Hawksbill was recorded during 12/13 September 1988 (Thomas et al. 1989). No Hawksbills were seen during turtle tagging operations on the atoll, 1-11 August 1992, but a member of the research team recalled seeing several swimming in the lagoon during an earlier visit in 1978 (Puleloa and Kilma 1992). Ronald Albert (in Eckert 1992) stated that Hawksbills have been reported to nest on Bikar and several other northern atolls, but did not mention any specific records.

Taka Atoll: A Hawksbill seen in the lagoon during 14/15 September 1988 was the only one encountered during a survey of 96 lagoon and ocean reef stations covering six atolls and Jemo Island, and with over 100 hours in the water during 7-24 September 1988 (Thomas et al. 1989). There are no other records for Taka Atoll.

Dermochelys coriacea (Vandelli) - Three or four Leatherbacks were reported seen in the water between Rongelap and Rongerik Atolls, September 2003, one of them in currents near a point of land on Rongelap Island (L. Tobin in McCoy 2004). There are no other records for the northern Marshalls and only a scattering of records from elsewhere in the Marshall Islands (McCoy 2004, 2008). The Leatherback is not known to nest in the RMI.

\section{Lizards}

\section{Geckos}

Gehyra oceanica (Lesson) - The Oceanic Gecko ranges widely in the Pacific from Indonesia and Papua New Guinea eastward to eastern Polynesia (Bauer and Henle 1994). It has been recorded in the northern Marshall Islands from Enewetak Atoll (Aniyaanii [=Ananii] 2, Elugelab 1, Igurin 6, Japtan/ David 3, Japtan [probably Japtan/David] 1, Rigili 2); Bikini Atoll (Bikini 8, Chieerete 2, Eninman [= Eman] 25, Namu 5, Ourukaen 3); Rongerik Atoll (Bock 1, Eniastok [probably a misspelling of Eniwetok] 1)-BPBM, 
TABLE 2

Summary of Distribution Records of 11 Species of Lizards in the Northern Marshall Islands, along with Number of Specimens Collected during March-April 2019; SR = sight records only.

\begin{tabular}{|c|c|c|c|c|c|c|c|c|c|c|c|}
\hline \multirow[b]{2}{*}{ Locality } & \multicolumn{11}{|c|}{ Species $^{\mathrm{a}}$} \\
\hline & G.o. & H.f. & L.1. & L.m. & C.p. & E.ca & E.cy & E.im & L.s. & L.n. & V.t. \\
\hline \multicolumn{12}{|l|}{ Ralik Chain } \\
\hline \multicolumn{12}{|l|}{ Enewetak Atoll } \\
\hline Alembel & & & + & + & & & & & & & \\
\hline Aniyaanii & + & & & & & & & & & & \\
\hline Billee & & & + & & & & & & & & \\
\hline Boken/Irene & & & + & & & & & & & & \\
\hline Boken/Irwin & & & + & & & & & & & & \\
\hline Elugelab & + & & & & & & & & & & \\
\hline Enewetak & & + & + & & & & & & & & \\
\hline Enjebi & & & + & & & & & & & & \\
\hline Igurin & + & & + & & & & + & & & + & \\
\hline Japtan/David & + & + & + & & & & + & & & + & + \\
\hline Lujor & & & & & & & + & & & & \\
\hline Mui & & & & & & & + & & & & \\
\hline Perry & & + & + & & & + & + & & & & \\
\hline Piirai & & & + & & & & + & & & & \\
\hline Ribewon & & & + & & & & & & & & \\
\hline Rigili & + & & + & & & & & & & & \\
\hline Runit & & + & & & & & + & & & + & \\
\hline Van & & & + & & & & & & & & \\
\hline \multicolumn{12}{|l|}{ Bikini Atoll } \\
\hline Airukiiji & & $2^{*}$ & & & & & & & & & \\
\hline Aomoen & & & $13^{* \dagger}$ & & & & + & + & & & \\
\hline Bikini & + &,+ 4 &,+ 5 & & & & + & + & & & \\
\hline Bokororyuru & & & + & & & & + & & & & \\
\hline Chieerete & + & & + & & & & & & & & \\
\hline Eninman & + & & & & & & & + & & & \\
\hline Enyu & $\mathrm{SR}^{*}$ & &,+ 3 & & & &,+ 2 & + & & & \\
\hline Namu & + & &,+ 5 & & & & + & + & & & \\
\hline Ourukaen & + & & + & & & & & + & & & \\
\hline Romurikku & & &,+ 1 & & & & + & + & & & \\
\hline Yurochi & & & $1^{*}$ & & & & & & & & \\
\hline \multicolumn{12}{|l|}{ Ailinginae Atoll } \\
\hline Enibuk & $1_{*}^{*}$ & & $1_{*}^{*}$ & & & & $1^{*}$ & $4^{*}$ & & & \\
\hline Knox & $2^{*}$ & & $4^{*}$ & & & & & & & & \\
\hline Mogiri & & & $3^{*}$ & & & & & & & & \\
\hline Sifo & $3^{*}$ & & $3^{*}$ & & & & & $1^{*}$ & & & \\
\hline \multicolumn{12}{|l|}{ Rongelap Atoll } \\
\hline Burok & & & + & & & & & & & & \\
\hline Erapuotsu & & & + & & & & & & & & \\
\hline Kabelle & & & + & & & & & & & & \\
\hline Naen & & &,+ 3 & & & & + & + & & & \\
\hline Rongelap & $3^{*}$ & $4^{*}$ & + & & & & & $1^{*}$ & & & \\
\hline \multicolumn{12}{|l|}{ Rongerik Atoll } \\
\hline Bigonattam & & & & & & & & + & & & \\
\hline Bock &,+ 2 & & & & & & & & & & \\
\hline Eniwetak &,+ 1 & & $3^{*}$ & & & & & $2^{*}$ & & & \\
\hline Latoback & & & & & & & + &,+ 1 & & & \\
\hline Rongerik & $1^{*}$ & &,+ 4 & + & & & &,+ 2 & $+{ }^{\mathrm{SR}}$ & & \\
\hline \multicolumn{12}{|l|}{ Ratak Chain } \\
\hline \multicolumn{12}{|l|}{ Bokak Atoll } \\
\hline Bokak & & $2^{*}$ & & & $4^{* \dagger}$ & & & & & & \\
\hline Sibylla & & $12^{*}$ & & &,+ 7 & & & & & & \\
\hline
\end{tabular}


TABLE 2

\begin{tabular}{|c|c|c|c|c|c|c|c|c|c|c|c|}
\hline \multirow[b]{2}{*}{ Locality } & \multicolumn{11}{|c|}{ Species $^{\mathrm{a}}$} \\
\hline & G.o. & H.f. & L.1. & L.m. & C.p. & E.ca & E.cy & E.im & L.s. & L.n. & V.t. \\
\hline \multicolumn{12}{|l|}{ Bikar Atoll } \\
\hline Bikar & & & + & & & & + & + & & & \\
\hline Jabwelo & & & + & & & & & & & & \\
\hline Utirik Atoll & & & & & & & & & & & \\
\hline Utirik & & $3^{*}$ & $4^{*}$ & & & & + &,+ 1 &,+ 1 & & \\
\hline Taka Atoll & & & & & & & & & & & \\
\hline Lojiron & & & & & & & + & & & & \\
\hline Taka & $1^{*}$ & & $2^{*}$ & & & &,+ 1 &,+ 2 & + & & \\
\hline Watwerok & & & + & & & & & & & & \\
\hline
\end{tabular}

${ }^{a}$ Geckos: G.o., Gehyra oceanica; H.f., Hemidactylus frenatus; L.1., Lepidodactylus lugubris; L.m., Lepidodactylus moestus. Skinks: C.p., Cryptoblepharus poecilopleurus; E.ca, Emoia caeruleocauda; E.cy, Emoia cyanura; E.im, Emoia impar; L.n., Lipinia noctua; L.s., Lamprolepis smaragdina. Monitor lizards: V.t., Varanus tsukamotoi.

*First report, this study.

CAS-SUR, UF, USNM. To this list we add the first records for Ailinginae, Rongelap, and Taka Atolls, along with Enyu Island, Bikini Atoll (one observed by D.T. on the cement walls of an old bunker, 15 April 2019), and Rongerik Island, Rongerik Atoll (Table 2). We encountered $G$. oceanica regularly in edificarian habitats as well as in forest under exfoliating bark of dead trees, where the bark could be removed in thick flakes, such as on Guettarda speciosa, but not under the thin paper-like peelings of Pisonia grandis.

Hemidactylus frenatus (Duméril \& Bibron) - The Common House Gecko is native to southern Asia and has been introduced widely in tropical and subtropical regions throughout the world (Ota and Whitaker 2010). It is a common human commensal usually found on or inside buildings and often seen feeding on insects attracted to lights at night. It spread rapidly throughout much of Oceania during and following WWII, probably as a result of increased frequency of military and commercial travel between the islands (Case et al. 1994, Hunsaker 1996, Crombie and Pregill 1999, Zug 2013, Buden and Taboroši 2016). However, Pregill and Weisler (2007) suggested a possible deeper history of this species in Micronesia based on a single bone they recovered from an archaeological site on Ebon Atoll in the southern Marshalls, and bones excavated from prehistoric strata in the northern Marianas (Pregill 1998). The oldest collection dates for living examples of this species in the Marshall Islands are 12 February 1950 for 20 specimens from Perry Island (KU 94423-94442), and 17 February for four others from Enewetak Island, Enewetak Atoll (KU 94419-94422). Its presence (and in some numbers) on at least two of the islands suggest it was already well established on the atoll at that time. Locality records of $H$. frenatus in the northern Marshalls include Enewetak Atoll (Enewetak 15, Japtan/David 1, Perry [= Parry $=$ Medren $] 80$, Runit $[=$ Uni $=$ Ruuit $=$ Yvonne] 7); Bikini Atoll (Bikini 1)—BPBM, CAS, KU, UMMZ, USNM. We herein report the first records for Rongelap, Bokak, and Utirik Atolls, and Airukiiji Island, Bikini Atoll (Table 2). The one previously collected specimen from Bikini Atoll (BPBM 10956) was collected by A. Y. Suzumoto on 26 July 1985. On Bokak Atoll, where edificarian habitats are lacking, $H$. frenatus is found mainly in dead, dry-rotted, hollowed-out limbs and trunks of Tournefortia argentea trees, being syntopic with Cryptoblepharus poecilopleurus, the only other lizard recorded from the atoll. However, it was scarce or absent in wooded habitats on islands where it was otherwise common in the settlements (e.g., Utirik and Bikini Atolls).

Lepidodactylus lugubris (Duméril \& Bibron) - The Mourning Gecko is a parthenogenetic unisexual species that appears to have arisen several centuries ago through a hybridization event between $L$. moestus and another 
(but as yet undescribed) native Pacific species (Radtkey et al. 1995). It ranges widely from Southeast Asia (Das 2010) southward to northern Australia and eastward across Oceania to the western coasts of Mexico and Central America (Bauer and Henle 1994), and with numerous introduced and established populations being recently reported in the New World (Hoogmoed and Avila-Pires 2015, Behm et al. 2019, and papers cited therein). It is the most common gecko and one of the most common lizards in the Marshall Islands (D.W.B., pers. obs.). Locality records from the northern Marshalls include: Enewetak Atoll (Arambiru [=Alembel] 1, Billee [= Lucy] 1, Boken/Irene 5, Boken/Irwin 1, Enwetak [= Fred] 24, Enjebi 12, Igurin 3, Japtan [probably Japtan/David] 1, Perry 26, Piirai 3, Ribewon 2, Rigili $[=$ Biken $=$ Leroy] 8, Van 2); Bikini Atoll (Bikini 27, Bokoroyuru 1, Chieerete 1, Enyu 2, Namu 6, Ourukaen 1, Romurikku [= Romuk] 3); Rongelap Atoll (Burok 1, Erapuotsu 1, Kabelle 1, Naen 1, Rongelap1); Rongerik Atoll (Rongerik 3); Bikar Atoll (Bikar 4, Jahoerrhu [=Jabwelo] 2); Taka Atoll (Watwerok 1) BPBM, CAS-SUR, HSU, LACM, MVZ, USNM. To this list we add the first records for Ailinginae and Utirik Atolls, along with Aomoen and Yurochi Islands (Bikini Atoll), Eniwetak Island (Rongerik Atoll), and Taka Island (Taka Atoll) (Table 2). [Note: The 24 specimens from Enewetak (=Fred) Island, Enewetak Atoll, include HSU 253 (a group of eight specimens) and HSU 254 (six specimens) collected on "Fred Island, Sand Island" by W.J. Houck on 23 July 1979 and 23 July 1983, respectively. There is no island officially known as Sand Island on Enewetak Atoll, and Houck may have been referring to a nearby unnamed islet adjacent to Fred or to a specific part of Fred itself.]

Lepidodactylus moestus (Peters) - The Micronesian Scaly-toed Gecko ranges from Palau, in the western Caroline Islands, eastward across the Federated States of Micronesia to the Marshall Islands (Buden and Taboroši 2016). The only locality records from the northern Marshalls include one specimen from Rongerik Island, Rongerik Atoll (CAS-SUR 12184) collected by G. S.
Meyers, August 1947, and two others from Alembel [= Arambiru = Vera] Island, Enewetak Atoll (USNM 205534, 205535) collected by P. B. and J. Lamberson, 17 April 1977. The Enewetak specimens were initially identified as Hemiphyllodactylus typus in Lamberson's (1987a) review, later reidentified as Lepidodactylus sp. by Crombie and Pregill (1999), and subsequently recorded as L. moestus in VertNet and USNM online databases; see also Fisher et al. (2013). This species was long included in the synonymy of L. lugubris until resurrected by Ota et al. (1995) and it is possible that other examples of L. moestus from the Marshalls lie hidden among museum specimens identified as L. lugubris.

\section{Skinks}

Cryptoblepharus poecilopleurus (Wiegmann) - The Oceania Snake-eyed Skink is widely distributed in the Pacific (Zug 2013, Allison et al. 2016), but it is known in the Marshall Islands only from the 19 specimens collected on Bokak Atoll-six from Sibylla Island during a northern Marshall Islands expedition led by F. R. Fosberg, 20-26 July 1952 (USNM 132439-132444), two others (island unstated) during a Smithsonian Pacific Ocean Biological Survey Project expedition, 12 October 1964 (USNM 156984, 156985), and the 11 we collected on Sibylla and Bokak Islands during 4-6 April 2019 (Table 2)—see Discussion. We frequently encountered $C$. poecilopleurus in dry-rotted and hollowed-out limbs and trunks of Tournefortia argentea trees, as well as under pieces of driftwood, cardboard, and other debris lying on the ground. It is syntopic with the Common House Gecko, Hemidactylus frenatus, the only other lizard recorded on the atoll. An encounter rate of about $40 / \mathrm{hr}$ for $C$. poecilopleurus was derived from a brief (15 min) survey count on Sibylla Island by D.W.B. on 5 April.

Emoia caeruleocauda (De Vis) - The Pacific Blue-tailed Skink is widespread throughout the Indo-Pacific region (Gonzalez et al. 2012) and is the most broadly distributed of Pacific skinks (Zug 2013). However, it is much less common in the Marshalls than are 
its two morphologically similar congeners, $E$. cyanura and $E$. impar, with the only record from the northern islands being KU 94512, collected on Perry Island, Eniwetok [= Enewetak] Atoll, 12 February 1950. Photographs of the specimen provided by museum staff are for the most part inconclusive, but broad, rounded subdigital lamellae that distinguish this species from E. cyanura and $E$. impar are discernible in some views.

Emoia cyanura (Lesson) — The Whitebellied Copper-striped Skink is widespread but spottily distributed among the islands of the Pacific (Ineich and Zug 1991, Zug 2013, Buden and Taboroši 2016). It is one of the most common lizards in the Marshall Islands, where it is most frequently found in coastal strand and other open, sun-exposed areas (D.W.B. pers. obs.). In the northern Marshalls, it has been recorded from Enewetak Atoll (Igurin 17, Japtan/David [= Muti] 5, Japtan [probably Japtan/David] 1, Lujor 2, Mui $[=$ Mut $] 5$, Perry $[=$ Parry $=$ Medren $=$ Elmer] 28 [including KU 94513-94516 recorded under the synonym E. pheonura], Piirai 2, Runit 4); Bikini Atoll (Aomoen 6, Bikini 18, Bokororyuru 1, Enyu 1, Namu 6, Romurikku 1); Rongelap Atoll (Naen 1); Rongerik Atoll (Latoback 5); Bikar Atoll (Bikar 1); Utirik Atoll (Utirik 1); Taka Atoll (Logiron 1, Taka 1)-AMNH, BPBM, CASSUR, KU, MVZ, USNM [Note: USNM 124082 is recorded as from Billae Islet in Lamberson (1987a), but from Igurin, on the opposite (southern) side of the atoll, in the USNM online database as well as in the original handwritten entry in the museum catalog]. To the list of localities we add the first records for Ailinginae Atoll (Table 2).

Emoia impar (Werner) — The Dark-bellied Copper-striped Skink is widespread but spottily distributed across the Pacific from the Bismarck Archipelago eastward to Polynesia (Ineich and Zug 1991, Zug 2013). It is one of the most common lizards in the Marshall Islands, being found in open as well as forested habitats (D.W.B., pers. obs.). Locality records for the northern Marshalls include: Bikini Atoll (Aomoen 12, Bikini 16, Eninman 14,
Enyu 1, Namu 18, Ourukaen 1, Romurikku 2); Rongelap Atoll (Naen 2); Rongerik Atoll (Bigonattam 5, Latoback 13, Rongerik 14); Bikar Atoll (Bikar 2), Utirik Atoll (Utirik 6); Taka Atoll (Taka 2)-BPBM, CAS-SU, UF, USNM. To this list we add the first records for Ailinginae Atoll and Rongelap Island, Rongelap Atoll, and Eniwetak Island, Rongerik Atoll (Table 2). The absence of records from Enewetak Atoll is puzzling in view of relatively extensive sampling on the atoll and numerous records of this species from elsewhere in the northern Marshalls.

Lamprolepis smaragdina (Lesson) - The Emerald Tree Skink ranges widely from the Philippines and Indonesia east of Wallace's Line eastward to New Guinea and the Islands of the western Pacific (Linkem et al. 2013). Although common in the central and southern Marshalls (D.W.B., pers. obs.), it appears to be almost completely absent from the northern atolls, where it has been collected only on Utirik Atoll (Utirik Island, USNM 132191132199, northern Marshall Islands expedition, 1952) and on nearby Taka Atoll (Taka Island, USNM 156975-156980, Smithsonian Pacific Ocean Biological Survey Program expedition, 1964). However, Thomas et al. $(1989: 48,70)$ mentioned "green tree geckos (Lamprolepis sp.)" seen on Taka Island, Taka Atoll and "green tree geckos" on Rongerik Island, Rongerik Atoll, in September 1988, presumably referring to L. smaragdina. We observed L. smaragdina in small numbers on Utirik Island, and mainly on the trunks of coconut trees; all had brown (or greenish brown or yellowish brown) dorsa. We saw none on Taka Atoll nor on any of the other northern atolls outside of Utirik.

Lipinia noctua (Lesson) — The Moth Skink ranges widely throughout the Pacific islands (Austin 1999, Zug 2013), but is known in the Marshall Islands only from Enewetak Atoll in the north, and Arno Atoll in the south. Lamberson (1987a:328) considered it "fairly common on Enewetak Atoll among leaf litter and coconut debris." She remarked on 36 specimens from Ikuren (20), Japtan (6), and Runit (10) Islands in AMNH, BPBM, and 
USNM collections. There are no other records. Time constraints prevented our visiting Enewetak and we are unable to comment on its present status on the atoll.

\section{Monitor lizards}

Varanus tsukamotoi Kishida - In a recently revised taxonomy of the monitor lizards of western Micronesia, Weijola et al. (2020) resurrected the name Varanus tsukamotoi Kishida, 1929, and recommended the common name Mariana Monitor, for populations on Guam, Rota, Tinian, Saipan, Anathan, and Pagan Islands in the Mariana Islands and the presumed introduced population on Enewetak Atoll in the Marshall Islands (see Discussion). Four specimens from Enewetak Atoll are the only records for the northern Marshalls (Lamberson 1987a; VertNet database, accessed 27 May 2019): one recorded from Japtan/David (USNM 252421, 1 September 1975 [almost certainly the same specimen recorded by Lamberson (1987a) as MPRL (no number), 15 September 1975]), and three others from Japtan Island (probably Japtan/David) (AMNH R78994 [no date], USNM 124112 and 124113, 7 June 1947). Monitors have been recorded elsewhere in the Marshalls on Aur and Wotje Atolls (National Biodiversity Team of the Republic of the Marshall Islands 2000), with occasional sightings of individuals in the past (but no evidence of established populations) on Majuro Atoll (Spennemann 1997), and Kwajalein Atoll (Fore 1999, S. and J. Johnson, pers. comm. and website www.underwaterkwaj.com/uwmisc/turtle/turtle.htm). The current status of population numbers in the RMI is unknown.

\section{Snakes}

Indotyphlops braminus (Daudin) — The Brahminy Blindsnake is native to southern Asia but has been introduced widely throughout the tropics and subtropics (excluding South America), and with limited encroachment into the North American temperate zone (Wallach 2009, Ineich et al. 2017). Its chief mode of dispersal appears to be via root masses or soil of transported agricultural and ornamental plants, thus earning it the alternative name, Flowerpot Snake. None was encountered during the 2019 expedition, and the seven specimens previously collected on Enewetak Atoll are the only records for the northern Marshalls: KU 94538, 94539 (Perry Island, 11 February 1950); MCZ 53782 (Perry Island, 1 June 1954); UWBM 4959, 4960 (Perry Island, 1958-cataloged as Typhlops sp. but almost certainly referable to I. braminus); MVZ 150321 (island unstated, 12 December 1978); BPBM 6953 (Enewetak Island, 13 September 1980).

The earliest recorded collection date for this species in the Marshall Islands has been reported as 1954 based on MCZ 53782 collected on "Parry [= Perry] Island, Eniwetok [= Enewetak] Atoll" (Knight 1984, Ineich et al. 2017). However, this specimen is predated by the two collected on Perry Island in 1950 , and earlier still by a specimen (BPBM 36995 ) collected in the southern Marshalls on Jaluit Island, Jaluit Atoll, 1 May 1938. The only other examples of I. braminus recorded in the Marshall Islands are UAZ 54916 (Kwajalein Atoll [no other locality], 1 May 1968); USNM 331430 (Kwajalein Atoll, Kwajalein Island, 1992-first reported on by Wallach 2008); BPBM 31543 (Majuro Atoll, Majuro Island, Laura Village, 19 November 2007); and one photographed on Arno Island, Arno Atoll during 1-4 July 2016 (Hinrich Kaiser et al. manuscript in prep).

\section{DISCUSSION}

Fifteen species of reptiles are known from the northern Marshall Islands, none endemic to the RMI. The gecko Lepidodactylus moestus has the most limited distribution, being known elsewhere only from the Caroline Islands (Palau and the Federated States of Micronesia) immediately to the west. The other species are widespread in the Pacific, and in many cases well beyond. Nearly all of those that have been assessed for the IUCN Red List of Threatened Species (either in publication or in draft status) are listed under the category "least concern," the only exceptions 
being the three sea turtles-Green Turtle, "endangered" (Seminoff 2004); Hawksbill, "critically endangered" (Mortimer and Donnelly 2008), and the western Pacific Ocean subpopulation of the Leatherback, “critically endangered" (Tiwari et al. 2013).

Although Green Turtles nest in varying numbers widely throughout the RMI, the inclusion of Bokak Atoll as a nesting site requires corroboration. Tobin (1952) indicated that within the northern Marshalls, Bokak, Bikar, and Taka Atolls, along with Jemo Island and parts of Erikub Atoll, have long been regarded as game reserves by the Marshallese because of the abundance of turtles and birds, which, along with their eggs, were periodically harvested. Hendrickson (1972) ranked Bokak among the most important nesting sites for Green Turtles in the Marshall Islands, and others have also included Bokak as a sea turtle nesting site; e.g., National Biodiversity Team of the Republic of the Marshall Islands (2000), Rudrud et al. (2007), Kabua and Edwards (2010). However, there is no substantive evidence relating specifically to Bokak as a nesting site for turtles, and the lack of evidence from previous surveys, as well as this study, speaks to the contrary. Fosberg $(1955,1969)$ recorded no turtles during a week-long stay in July 1952, and Thomas et al. (1989) saw no evidence of turtles on the atoll or in surrounding waters during a three-day visit in September 1988, although both expeditions found turtles nesting on Bokak's distant neighbor, Bikar. We saw no turtles or turtle tracks on Bokak Atoll during our visit, 4-6 April 2019. The inclusion of Bokak as a nesting site for sea turtles may be simply an inference based on its being a remote, uninhabited atoll in the northern part of the Ratak Chain, where turtles are known to nest abundantly on many of the other atolls. Turtles may nest on Bokak occasionally, but confirmation is needed.

The Olive Ridley, Lepidochelys olivacea, may occur in the northern Marshalls as a nonbreeding visitor from time to time but is as yet unrecorded. However, during 2005-2007, 19 $(58 \%)$ of 33 longline turtle interactions aboard fishing vessels operating out of Majuro, and within the nation's Exclusive
Economic Zone, involved Olive Ridleys (McCoy 2008); measurements taken on 17 indicated they were subadults. An Olive Ridley found alive on its back on a beach on Arno Island, Arno Atoll on 4 July 2016 is the only on-island record for the RMI. It was missing its right forelimb from an old injury and was assisted back into the water after being photographed (Kaiser et al. 2016).

Among terrestrial species of reptiles, the blindsnake, Indotyphlops braminus, the gecko, Hemidactylus frenatus, and the monitor lizard, Varanus tsukamotoi probably were introduced to the Marshalls in modern times, possibly since the early 1900s, but see species account for $H$. frenatus regarding archaeological findings reported by Pregill and Weisler (2007). To what extent the other species arrived via natural dispersal (e.g., rafting) or by human-assisted transport, either with the aboriginal colonists that arrived about 2,000 years ago (Weisler 2000), or later in the history of human occupation of the islands, is unknown.

\section{Monitor lizards in Micronesia}

Monitors appear to have been introduced to the Marshall Islands during the Japanese administration for rat control (Spennemann 1997, Biodiversity Team of the Republic of the Marshall Islands 2000) and as a possible source of food for the Japanese (Fisher 1948), as they apparently were also on many islands in the Federated States of Micronesia, immediately to the west of the Marshalls: e. g., Pohnpei Island (Fisher 1948), Mokil Atoll (Weckler 1949), Etal Atoll (Nason 1970), Lukunor Atoll (Borthwick 1977), Ifaluk Atoll (Bates and Abbott 1958, Uchida 1969). These and other Micronesian populations have long been included under the name Varanus indicus and reported to have been introduced during the Japanese administration. However, recent molecular and morphometric studies revealed that monitor lizards from western Micronesia form a distinct clade (and two separate species) and appear to have colonized those islands by natural dispersal several hundred thousand years ago rather than by more recent human-mitigated introduction (Weijola et al. 
2019, 2020). Weijola et al. (2020) described $V$. bennetti as a new species from Palau, Yap proper and Losiep Islands in the western Carolines, and Sarigan Island in the Commonwealth of the Northern Marianas (CNMI), and they resurrected the name $V$. tsukamotoi Kishida for populations on Guam and the CNMI (excluding Sarigan), along with the presumed introduced population on Enewetak Atoll in the Marshall Islands. But eastern Micronesia populations, including most of the Federated States of Micronesia and the Marshall Islands (excluding Enewetak), have not yet been assessed. Early reports of monitors and descriptions of lizards probably referring to monitors in the FSM predate the Japanese administration and suggest a longer history of Varanus in this region than is generally thought: de la Corte (1875) mentioned "iguanas" on Pohnpei, Cabeza Pereiro (1895) identified a large lizard that he saw on Pohnpei during the 1890s as a monitor, and Lesson (1839 as translated by Ritter and Ritter 1982:48) reported seeing a gecko and two other kinds of lizards on Kosrae during 5-15 June 1824, a greencolored species [probably Lamprolepis smaragdina] and one with a blue tail and golden stripes on its back [almost certainly Emoia sp.], but was told there was also "a kind of big lizard who could climb trees," possibly referring to monitors, which are common in some parts of the island (Buden pers. obs.). Continued molecular and morphological studies of Pacific island monitors are needed to further resolve their phylogenetic relationships, but their protected status makes acquisition of samples difficult.

\section{Distribution of lizards in the Marshalls- northern vs southern islands}

Species of lizards unrecorded in the northern atolls but found elsewhere in the Marshall Islands include the geckos Gebyra insulensis [recently documented by Kaiser et al., manuscript in prep.], Nactus pelagicus, and Perochirus ateles, and the skinks Emoia boettgeri, E. arnoensis, E. jakati, and Eugongylus albofasciolatus [Note: A series of 11 geckos (UNR 6308-6318) collected by Ira La Rivers on
Arno Atoll, in the southern Marshalls, JuneAugust 1950, were identified as Hemidactylus garnotii on the original specimen tags and in the VertNet online database (accessed November 2019). The specimens were reexamined for this study by C. Feldman, V. Thill, and J. Deboer of the UNR Museum of Natural History, and by visiting herpetologist, A. Bauer. The specimens were reidentified as L. lugubris.]. The absence of these "southern" species from the northern atolls may be an artifact of sampling, or due in part to the more arid conditions that provide less than optimal habitat. In contrast to the apparent absence of these somewhat unexpectedly missing species in the north, Cryptoblepharus poecilopleurus, the Oceania Snake-eyed Skink, is the only reptile found in the northern Marshalls that is unrecorded elsewhere in the RMI.

\section{Cryptoblepharus poecilopleurus-The Bokak Population}

The Oceania Snake-eyed Skink, ranges widely but somewhat spottily throughout the Pacific region, being recorded from Palau, the Mariana Islands, Wake Island, Marshall Islands, and the Hawaiian Islands in the north, to the Solomon Islands, Gilbert Islands (now a part of the Republic of Kiribati), Samoa, Tonga, Line Islands, Phoenix Islands (part of Kiribati), Cook Islands, French Polynesia, Pitcairn Islands, and Easter Island in the south, together with a scattering of predominately coastal records from Ecuador, Peru, and Chile in South America (Horner 2007, Allison et al. 2016). In the Marshall Islands, it is known only from Bokak Atoll.

The source of the Bokak population of C. poecilopleurus and its mode of dispersal to this tiny, remote atoll remain conjectural. Its apparent absence elsewhere in the Marshalls to the south, as well as from the hundreds of islands within the Federated States of Micronesia to the west, make derivation from these directions via island hopping unlikely. The population geographically closest to Bokak is on Wake Island, $570 \mathrm{~km}$ to the north and with no intervening stepping-stone islands. Possibly C. poecilopleurus reached Bokak by 
human-assisted transport in vessels arriving from Wake, or over even greater distances from the Mariana Islands to the west, or Hawaii to the northeast. The Japanese military had garrisons on both Wake and Bokak during WWII, with Bokak personnel being relocated to Wake in March 1943 because living conditions on Bokak were considered untenable (Rear Admiral Sakaibara [former commander, Japanese garrison, Wake Island] in US Navy Department 1946). Also, Japanese feather collectors visited Wake and Bokak as well as other Pacific Islands during the early 1900s to obtain feathers for the flourishing millinery trade (Spennemann $1998 a, b)$. Furthermore, to what extent commercial fishing vessels or private yachts have stopped at Bokak after coming from areas where $C$. poecilopleurus occurs is unknown, as visits to this remote and uninhabited atoll are not monitored.

Alternatively, C. poecilopleurus may have reached Bokak by natural drift dispersal on vegetation or driftwood from the Hawaiian Islands, about $3,500 \mathrm{~km}$ to the northeast, being carried on the north equatorial current and possibly assisted by northeast tradewinds. The importance of long-distance oceanic dispersal in historical biogeography has been underestimated for many years after being largely supplanted by vicariance models involving plate tectonics and continental drift (de Queiroz 2005). More recently, however, an increasing number of molecular studies have supported hypotheses of natural transoceanic dispersal of lizards (and other biota) over distances often exceeding 5,000 km: e.g., the arrival of the gecko genus Tarentola in Cuba from Africa (Carranza et al. 2000), the colonization of Andaman and Nicobar Islands by geckos of the genus Phelsuma from Madagascar (Austin et al. 2004), the colonization of western Indian Ocean islands by Cryptoblepharus from Australia or Indonesia (Rocha et al. 2006), and a global intercontinental dispersal of amphisbaenians (worm lizards) whose distribution was previously attributed to vicariance models (Vidal et al. 2008, Longrich et al. 2015). Lending credence to a Hawaii-to-Bokak drift dispersal hypothesis for C. poecilopleurus is the battered hull of a small fishing boat that was lost at sea off the coast of Maui Island in 1979 and found partially buried in the sand on Bokak Atoll in 1988 (Thomas et al. 1989). However, genetic studies are needed for a more definitive assessment of the origin and phylogenetic relationships of the Bokak population of C. poecilopleurus.

\section{ACKNOWLEDGMENTS}

For providing information on museum specimens in their care, we thank Kevin de Queiroz (National Museum of Natural History, Smithsonian Institution), David Dickey and David Kizirian (American Museum of Natural History), Chris Feldman, Vicki Thill, and Jonathan Deboer (University of Nevada, Reno, Museum of Natural History), Molly Hagemann (Bishop Museum), Richard Glor and Ana Motta (University of Kansas Biodiversity Institute), Sharyn Marks and graduate student assistant Sabrina Horrack (Humboldt State University Vertebrate Museum), Lauren Scheinberg (California Academy of Sciences), and Greg Schneider (University of Michigan Museum of Zoology). We also thank Aaron Bauer for his input regarding reidentification of misidentified geckos from Arno Atoll, George Balazs and Mike Mc Coy for providing literature on sea turtles in the Marshalls, Susanne Rust (reporter, Los Angeles Times) for sharing her observations on hatchling turtles on Bikini Atoll, Van Wallach for reviewing an early draft of the Indotyphlops braminus species account, Scott Johnson, biologist and former resident of Kwajalein, for information on monitor lizard sightings on Kwajalein Atoll, Fred Kraus for information on recent and ongoing studies of monitor lizards in Micronesia, and F. Kraus and A. Bauer also for reviewing the manuscript. We also thank Captain Elmi Juonran and the crew of the Okeanos Marshall Islands for their outstanding seamanship and providing for the safety and comfort of the research team under sometimes difficult and occasionally harrowing circumstances. 


\section{Literature Cited}

Abella, M. K. I. L., M. R. Molina, I. NikolicHughes, E. W. Hughes, and M. A. Ruderman. 2019. Background gamma radiation and soil activity measurements in the northern Marshall Islands. PNAS 116:15425-15434. https://doi.org/10.1073/ pnas.1903421116.

Allison, A., A. Hamilton, O. Tallowin, M. Vidal, C. Tala, J. C. Ortiz, H. Nunez, C. Garin, R. Avilés, J.Mella,J.Nunez, N. Sallabery, and P. Victoriano. 2016. Cryptoblepharus poecilopleurus. The IUCN Red List of Threatened Species 2016: e.T196597A115339544. http://dx.doi.org/10.2305/IUCN.UK.20161.RLTS.T196597A2464304.en. Accessed 22 May 2019.

Amerson, A. B., Jr. 1969. Ornithology of the Marshall and Gilbert Islands. Atoll Res. Bull. 127:1-348.

Austin, C. C. 1999. Lizards took the express train to Polynesia. Nature 397:113-114.

Austin, J. J., E. N. Arnold, and C. J. Jones. 2004. Reconstructing an island radiation using ancient and recent DNA: The extinct and living day geckos (Phelsuma) of the Mascarene Islands. Mol. Phylogenet. Evol. 16:37-48.

Bates, M., and D. P. Abbott. 1958. Coral island: Portrait of an atoll. Scribners, New York.

Bauer, A. M., and K. Henle. 1994. Familia Gekkonidae (Reptilia, Sauria). Part 1. Australia and Oceania. Das Tierreich 109:1-306.

Behm, J. E., G. van Buurt, B. M. DiMarco, J. Ellers, C. G. Irian, K. E. Langhans, K. McGrath, T.J. Tran, and M. R. Helmus. 2019. First records of the mourning gecko (Lepidodactylus lugubris Duméril and Bibron, 1836), common house gecko (Hemidactylus frenatus in Duméril, 1836), and Tokay gecko (Gecko gecko Linnaeus, 1758) on Curaçao, Dutch Antilles, and remarks on their Caribbean distributions. Bioinvasions Rec. 8:34-44. https://doi.org/ 10.3391/bir.2019.8.1.04.

Bender, B. W. 1963. A linguistic analysis of the place-names of the Marshall Islands. Ph.D. diss., Indiana University, Bloomington, Indiana.
Borthwick, M. 1977. Aging and social change on Lukunor Atoll, Micronesia. Ph.D. diss., University of Iowa, Iowa City.

Bridges, K. W., and W. McClatchey. 2005. Complementing PABITRA high-island studies by examining terrestrial plant diversity on atolls. Pac. Sci. 59:261-272.

Bryan, E. H., Jr. 1971. Guide to place names in the Trust Territory of the Pacific Islands. Pacific Science Information Center, Bishop Museum, Honolulu. Unpaged.

Buden, D. W., and D. Taboroši. 2016. Reptiles of the Federated States of Micronesia. Island Research and Education Initiative (iREi), Palikir. Pohnpei.

Cabeza Pereiro, A. 1895. La isla de Ponape. Chofré, Manila.

Carranza, S., E. N. Arnold, J. A. Mateo, and L. F. López-Jurado. 2000. Long-distance colonization and radiation in gekkonid lizards, Tarentola (Reptilia: Gekkonidae), revealed by mitochondrial DNA sequences. Proc. R. Soc. Lond. 267:637-649.

Case, T. J., D. T. Bolger, and K. Petren. 1994. Invasions and competitive displacement among house geckos in the tropical Pacific. Ecology 75:464-477.

Crombie, R. I., and G. K. Pregill. 1999. A checklist of the herpetofauna of the Palau Islands (Republic of Belau), Oceania. Herpetol. Monogr. 13:29-80.

Das, I. 2010. A field guide to the reptiles of South-East Asia. New Holland Publishers (UK) Ltd., London.

Eckert, S. 1992. Trip report: Republic of the Marshall Islands, 16-22 May 1992, by Coordinator, US Pacific Sea Turtle Recovery Team, National Marine Fisheries Service, Southwest Region. Manuscript.

Fisher, H. I. 1948. Locality records of Pacific island reptiles and amphibians. Copeia 1948:69.

Fisher, R. N., M. Uili, F. Enoka, and G. R. Zug. 2013. Clarifying the distribution records for Hemiphyllodactylus typus (Bleeker, 1860) from central Oceania. Herpetol. Notes 6:247-250.

Fore, B. 1999. New resident identified as a mangrove monitor lizard. Kwajalein Hourglass 39:10. 
Fosberg, F. R. 1955. Northern Marshall Islands expedition, 1951-1952, narrative. Atoll Res. Bull. 38:1-36.

- 1969. Observations on the green turtle in the Marshall Islands. Atoll Res. Bull. 135:9-12.

- 1988. Vegetation of Bikini Atoll, 1985. Atoll Res. Bull. 351:1-28.

-1990. A review of the natural history of the Marshall Islands. Atoll Res. Bull. 330:1-100.

Gonzalez, J. C., A. C. Diesmos, A. Allison, A. Hamilton, and O. Tallowin. 2012. Emoia caeruleocauda. The IUCN Red List of Threatened Species 2012: e.T195301A2377567. http://dx.doi.org/10.2305/IUCN.UK.2012. RLTS.T195301A2377567.en. Accessed 22 July 2019.

Helfrich, P., and R. May. 1987. Research at Enewetak Atoll: a historical perspective. Pages 1-16 in D. M. Devaney, E. S. Reese, B. L. Burch, and P. Helfrich, eds. The natural history of Enewetak Atoll. Vol. 1. The ecosystem: Environments, biotas, and process. U.S. Department of Energy, Oak Ridge, Tennessee.

Hendrickson, J. R. 1972. South Pacific Islands -marine turtle resources. Report prepared for the South Pacific Islands Fisheries Development Agency. FAO Report FI: SF/SOP/REG 102/6, FAO, Rome.

Hoogmoed, M. S., and T. C. S. Avila-Pires. 2015. Lepidodactylus lugubris (Duméril \& Bibron 1836) (Reptilia: Gekkonidae), an introduced lizard new for Brazil, with remarks on and correction of its distribution in the New World. Zootaxa 4000:90110.

Horner, P. 2007. Systematics of the snakeeyed skinks, Cryptoblepharus Wiegmann (Reptilia: Squamata: Scincidae)—an Australia-based review. The Beagle, Supplement 3:21-198.

Hunsaker, D. 1996. Notes on the population expansion of the house gecko, Hemidactylus frenatus. Philipp. J. Sci. 95:121-122

Ineich, I., A. Wynn, C. Giraud, and V. Wallach. 2017. Indotyphlops braminus (Daudin, 1803): distribution and oldest record of collection dates in Oceania, with report of a newly established population in French Polynesia (Tahiti Island, Society Archipelago). Micronesica 2017:1-13.

Ineich, I., and G. R. Zug. 1991. Nomenclatural status of Emoia cyanura (Lacertilia, Scincidae) populations in the central Pacific. Copeia 1991:1132-1136.

Kabua, E. N., and F. Edwards. 2010. Republic of the Marshall Islands (RMI) marine turtle legislation review. Secretariat of the Pacific Regional Environment Program (SPREP), Apia, Samoa.

Kaiser, H., M. M. Lewis, K. J. Ricker, M. M. Hull, and M. J. Zambada. 2016. First verified observation of the Olive Ridley Sea Turtle (Lepidochelys olivacea) in the Republic of the Marshall Islands. Herpetol. Notes 9:311-314.

Knight, J. L. 1984. Geographic distribution: Typhlina bramina. Herpetol. Rev. 15:115.

Lamberson, J. O. 1987a. Reptiles of Enewetak Atoll. Pages 325-329 in D. M. Devaney, E. S. Reese, B. L. Burch, and P. Helfrich, eds. The natural history of Enewetak Atoll. Vol. 2. Biogeography and systematics. U.S. Department of Energy, Oak Ridge, Tennessee.

- 1987b. Natural history of terrestrial vascular plants of Enewetak Atoll. Pages 17-35 in D. M. Devaney, E. S. Reese, B. L. Buch, and P. Helfrich, eds. The natural history of Enewetak Atoll. Vol. 2. Biogeography and systematics. U. S. Department of Energy, Oak Ridge, Tennessee.

Linkem, C. W., R. M. Brown, C. D. Siler, B. J. Evans, C. C. Austin, D. T. Iskander, A. C. Diesmos, J. Supriatna, N. Andayani, and J. A. McGuire. 2013. Stochastic faunal exchanges drive diversification in widespread Wallacean and Pacific island lizards (Squamata: Scincidae: Lamprolepis smaragdina). J. Biogeor. 40:507-520. https://doi. org/10.1111/jbi.12022.

Lippert, Z. 2017. Bikini Atoll corals may give insight into cancer treatment. The Stanford Daily, 14 July 2017.

Longrich, N. R., J. Vinther, R. A. Pyron, D. Pisani, and J. A. Gauthier. 2015. Biogeography of worm lizards (Amphisbaenia) driven by end-Cretaceous mass extinction. 
Proc. R. Soc. B 282:20143034. http://dx. doi.org/10.1098/rspb.2014.3034.

Maison, K. A., I. Kinan-Kelly, and K. P. Frutchey. 2010. Green turtle nesting sites and sea turtle legislation throughout Oceania. NOAA Technical Memorandum. NMFS-F/SPO-110. National Marine Fisheries Service, Pacific Islands Regional Office, Protected Resources Division, Honolulu, Hawaii.

McCoy, M. A. 2004. Defining parameters for sea turtle research in the Marshall Islands. Administrative Report AR-PIR08-04. U.S. Department of Commerce, National Oceanic and Atmospheric Administration, National Marine Fisheries Service, Pacific Island Region, Honolulu, Hawaii.

2008. Marshall Islands sea turtlefisheries interaction outreach and education, phase 2, final report. NOAA Marine Fisheries Service, Pacific Island Region, Honolulu, Hawaii.

Mortimer, J. A., and M. Donnelly. 2008. Eretmochelys imbricata. The IUCN Red List of Threatened Species 2008: e. T8005A12881238. http://dx.doi.org/10.2305/ IUCN.UK.2008.RLTS.T8005A12881238. en. Accessed 29 July 2019.

Mueller-Dombois, D., and F. R. Fosberg. 1998. Vegetation of the tropical Pacific islands. Springer-Verlag, New York.

Nason, J. D. 1970. Clan and copra: Modernization on Etal Island, eastern Caroline Islands. Ph.D. diss., University of Washington, Seattle.

National Biodiversity Team of the Republic of the Marshall Islands. 2000. The Marshall Islands-Living atolls amidst the living sea: The national biodiversity report of the Republic of the Marshall Islands. St. Hildegard Publishing, Santa Clarita, California.

Ota, H., and A. H. Whitaker. 2010. Hemidactylus frenatus. The IUCN Red List of Threatened Species 2010: e.T176130A7184890. http:// dx.doi.org/10.2305/IUCN.UK.2010-4. RLTS.T176130A7184890.en. Accessed 23 May 2019.
Ota, H., R. N. Fisher, I. Ineich, and T. J. Case. 1995. Geckos of the genus Lepidodactylus (Squamata: Reptilia) in Micronesia: Description of a new species and reevaluation of the status of Gecko moestus, Peters1867. Copeia 1995:183-195.

Pregill, G. K. 1998. Squamate reptiles from prehistoric sites in the Mariana Islands. Copeia 1998:64-75.

Pregill, G. K., and M. I. Weisler. 2007. Lizards from prehistoric sites on Ebon Atoll, Marshall Islands. Micronesica 39:107-116.

Pritchard, P. C. H. 1977. Marine turtles of Micronesia. Chelonia Press, San Francisco, California.

Puleloa, W. K., and N. Kilma. 1992 [manuscript]. The sea turtles of the northern Marshalls: A research expedition to Bikar and Erikup Atolls, and Jemo Island. Unpublished report to SPREP. $72 \mathrm{pp}$.

de Queiroz, A. 2005. The resurrection of oceanic dispersal in historical biogeography. Trends Ecol. Evol. 20:68-73.

Radtkey, R. R., S. C. Donnellan, R. N. Fisher, C. Moritz, K. A. Hanley, and T. J. Case. 1995. When species collide: the origin and spread of an asexual species of gecko. Proc. R. Soc. Lond. 259:145-152.

Ritter, T. L., and P. L. Ritter [translators and editors]. 1982. The European discovery of Kosrae Island: Accounts by Louis Isidore Duperrey, Jules Sébastien César Dumont D’Urville, René Primevère Lesson, Fyedor Lütke, and Friedrich Heinrich von Kittlitz. Micronesian Archaeological Survey Report Number 13. Historic Preservation Office, Trust Territory of the Pacific Islands, Saipan.

Rocha, S., M. A. Carretero, M. Vences, F. Glaw, and D. J. Harris. 2006. Deciphering patterns of transoceanic dispersal: the evolutionary origin and biogeography of coastal lizards (Cryptoblepharus) in the western Indian Ocean region. J. Biogeogr. 33:13-22.

Rudrud, R. W., J. W. Kroeker, H. Y. Leslie, and S. S. Finney. 2007. The sea turtle wars: culture, war and sea turtles in the Republic of the Marshall Islands. SPC Traditional 
Marine Resource Management and Knowledge Information Bulletin 21:3-29.

Rust, S. 2019. Radiation in parts of the Marshall Islands is far higher than Chernobyl, study says. Los Angeles Times, 15 July 2019. Available online at https://www. latimes.com/nation/la-na-marshall-islandsradiation-20190715-story.html.

Scott, S. 2017. What Bikini Atoll looks like today. Stanford Magazine, 20 November 2017. Available online at https://medium.com/stan ford-magazine/stanford-research-on-effectsof-radioactivity-from-bikini-atoll-nucleartests-on-coral-and-crab-dna-48459144020c.

Seminoff, J. A. 2004. Chelonia mydas. The IUCN Red List of Threatened Species 2004: e.T4615A11037468. http://dx.doi. org/10.2305/IUCN.UK.2004.RLTS.

T4615A11037468.en. Accessed 29 July 2019.

Spennemann, D. H. R. 1997. Distribution of rat species (Rattus spp.) on the atolls of the Marshall Islands: past and present dispersal. Atoll Res. Bull. 446:1-18.

- 1998a. Japanese poaching and the enforcement of German colonial sovereignty in the Marshall Islands. J. Pac. Hist. 33:51-68.

— 1998b. Japanese exploitation of central Pacific seabird populations, 1898-1915 . Pac. Stud. 21:1-41.

Stevens Releford, J. 2009. The botany of Rongelap Atoll: A survival story. Ph.D. diss., University of Hawaii at Manoa, Honolulu.

Stevens Releford, J., J. Stevens, K. W. Bridges, and W. C. McClatchey. 2009. Flora of Rongelap and Ailinginae Atolls. Atoll Res. Bull. 572:1-13.

Taylor, W. R. 1950. Plants of Bikini and other northern Marshall Islands. University of Michigan Press, Ann Arbor.

Thomas, P. E. J., F. R. Fosberg, L. S. Hamilton, D. R. Herbst, J. O. Juvik, J. E. Maragos, J. J. Naughton, and C. F. Streck. 1989. Report on the northern Marshall Islands natural diversity and protected areas survey, 7-24 September 1988. South Pacific Regional Environment Program (SPREP), Noumea, New
Caledonia, and East-West Center, Honolulu.

Tiwari, M., B. P. Wallace, and M. Girondot. 2013. Dermochelys coriacea West Pacific Ocean subpopulation. The IUCN Red List of Threatened Species 2013: e. T46967817A46967821. http://dx.doi.org/ 10.2305/IUCN.UK.2013-2.RLTS.

T46967817A46967821.en. Accessed 29 July 2019.

Tobin, J. 1952. Land tenure in the Marshall Islands. Atoll Res. Bull. 11:1-36

Uchida, T. A. 1969. Rat-control procedures on the Pacific islands, with special reference to the efficiency of biological control agents. 1. Appraisal of the monitor lizard, Varanus indicus (Daudin), as a rat-control agent on Ifaluk, western Caroline Islands. J. Fac. Agr. Kyushu Univ. 15:311-330.

U.S. Navy Department. 1946. Report of surrenders and occupation of Japan and Korea. Office of the Chief of Naval Operation, Washington, D.C.

Vidal, N., A. Azvolinsky, C. Cruaud, and S. B. Hedges. 2008. Origin of tropical American burrowing reptiles by transatlantic rafting. Biol. Lett. 4:115-118. https://doi.org/ 10.1098/rsbl.2007.0531.

Wallach, V. 2008. Range exensions and new island records for Ramphotyphlops braminus (Serpentes: Typhlopidae). Bull. Chicago Herp. Soc. 43:80-82.

- 2009. Ramphotyphlops braminus (Daudin): a synopsis of morphology, taxonomy, nomenclature and distribution (Serpentes: Typhlopidae). Hamadryad 34:34-61.

Weckler, J. E. 1949. Land and livelihood on Mokil. Part 1. Coordinated Investigations in Micronesian Anthropology (CIMA) Report Number 11. Pacific Science Board, National Research Council, Washington, D.C.

Weijola, V., V. Vahtera, C. Lindquist, and F. Kraus. 2019. A molecular phylogeny for the Pacific monitor lizards (Varanus subgenus Euprepiosaurus) reveals a recent and rapid radiation with high levels of cryptic diversity. Zool. J. Linn. Soc. 186:1053-1066. https://doi.org/10.1093/zoolin nean/zlz002. 
Weijola, V., V. Vahtera, A. Koch, A. Schmitz, and F. Kraus. 2020. Taxonomy of Micronesian monitors (Reptilia: Squamata: Varanus): endemic status of new species argues for caution in pursuing eradication plans. R. Soc. Open Sci. 7:20092. http://dx.doi. org/10.1098/rsos.20092.

Weisler, M. I. 2000. Burial artifacts from the Marshall Islands: descriptions, dating and evidence for extra-archipelago contacts. Micronesica 33:113-138. 2001a. Life on the edge: prehistoric settlement and economy on Utrōk Atoll, northern Marshall Islands. Archaeol. Oceania 36:109-133.

2001b. On the margins of sustainability: prehistoric settlement of Utrōk Atoll, northern Marshall Islands. BAR International Series 967. Oxford, United Kingdom.

Zug, G. R. 2013. Reptiles and amphibians of the Pacific islands: A comprehensive guide. University of California Press, Berkeley. 